\title{
Mobilitas Dan Persebaran Penduduk NTB (Perspektif Ekonomi dan Kesejahteraan)
}

\author{
Jalaludin \\ Fakultas Ekonomi dan Bisnis - Universitas Mataram \\ Coresponding Email: din.jalali@gmail.com
}

\section{Info Artikel}

Kata Kunci:

Penduduk, mobilitas, persebaran

\section{ABSTRAK}

Jumlah penduduk Provinsi Nusa Tenggara Barat (NTB) berdasarkan Sensus Penduduk 2020 adalah 5,32 juta jiwa dengan Laju Pertumbuhan Penduduk (LPP) 1,63 persen, lebih tinggi dari LPP nasional sebesar 1,25 persen. Kuantitas dan kualitas penduduk merupakan dua faktor utama dalam menganalisis masalah kependudukan, dimana keduanya bisa dikaji melalui tren, sebaran, pertumbuhan dan komposisinya, Sementara proses demografi seperti Fertilitas, Mortalitas dan migrasi atau mobilitas serta persebaran adalah faktor faktor yang mempengaruhi dinamika kependudukan itu sendiri. Persebaran dan mobilitas penduduk ibarat dua sisi mata uang yang tidak dapat dipisahkan dan keduanya merupakan determinan penting dalam kerangka pengendalian penduduk. Membicarakan masalah migrasi atau mobilitas penduduk, tidak begitu berarti bila tidak dikaitkan dengan masalah persebaran penduduk, demikian pula sebaliknya menyelesaikan persoalan persebaran penduduk tidak mungkin dilakukan tampa mobilisasi atau perpindahan penduduk. Dengan adanya mobilitas atau migrasi penduduk, pembangunan di daerah NTB semakin berkembang karena para migran umumnya adalah angkatan kerja dan biasanya memiliki semangat kerja dan semangat untuk maju yang besar dibandingkan dengan masyarakt local/ tempatan. Disamping itu kehadiran para migrant, dapat menciptakan lapangan kerja baru yang dapat mendukung pertumbuhan ekonomi daerah. Selain berdampak terhadap peningkatan ekonomi dan kesejahteraan, adanya mobilitas atau migrasi penduduk juga menyebabkan terjadinya perubahan terhadap persebaran penduduk NTB.

\section{ABSTRAK}

Based on the 2020 Population Census, West Nusa Tenggara has a population of 5.32 million people with a Population Growth Rate of $1.63 \%$, higher than the national rate of $1.25 \%$. 
Population quantity and quality are the two main factors in analyzing population problems that can be studied through trends, distribution, growth, and composition. Meanwhile, demographic processes such as fertility, mortality, migration or mobility, and distribution are factors that influence the dynamics of the population itself. The distribution and mobility are like two sides of a coin that cannot be separated, and both are important determinants in the framework of population control. The migration or mobility problems cannot be solved without relating to the population distribution and vice versa. Through the migration or mobility program, migrants that mostly are labor forces play a role in increasing development in the area of West Nusa Tenggara as those people have greater work and progress enthusiasms than the local community. In addition, the presence of migrants can create new jobs that can support regional economic growth. Along with improving the economy and welfare of the population, mobility or migration also causes changes in the distribution of the population of West Nusa Tenggara.

\section{PENDAHULUAN}

Penduduk merupakan modal dasar dan unsusr yang paling vital dalam pembangunan suatu bangsa/ daerah. Berbagai bukti empirik menunjukkan bahwa kemajuan suatu bangsa sebagian besar ditentukan oleh kualitas Sumber Daya Manusia (SDM) bukan oleh melimpahnya Sumber Daya Alam (SDA). Pertumbuhan ekonomi dan pembangunan sumber daya manusia (SDM) yang handal dan berkualitas tidak mungkin terwujud jika jumlah dan pertumbuhan penduduk tidak terkendali. Oleh karenanya pengendalian penduduk mutlak dilakukan jika kita ingin membangun pertumbuhan ekonomi dan sumber daya manusia yang berkualitas.

Untuk membangun kesadaran masyarakat dunia akan pentingnya pengendalian penduduk ini, Perserikatan Bangsa- Bangsa (PBB) menetapkan tanggal 11 Juli sebagai momentum peringatan hari populasi sedunia. Penetapan tanggal 11 Juli sebagai hari Kependudukan Dunia ini dilatari oleh peringatan "Hari Lima Miliar" penduduk dunia yang terjadi pada 1987. Sejak saat itu, populasi dunia terus bertambah dan berdampak pada meningkatnya permasalahan kependudukan (Zubaidah Hanum, 2020). Peringatan hari kependudukan sedunia dimaksudkan sebagai sarana untuk meningkatkan kesadaran semua negara dan warga dunia untuk lebih peduli terhadap kondisi dan dampak yang timbul akibat masalah kependudukan.

Secara kuantitas jumlah penduduk Indonesia adalah keempat terbesar di dunia setelah Cina, India dan Amerika Serikat, dengan laju pertumbuhan yang masih relatif tinggi. Berdasarkan hasil rilis resmi yang disampaikan oleh Kepala BPS RI penduduk Indonesia pada tahun 2020 mencapai 270,20 juta jiwa dengan Laju Pertumbuhan Penduduk (LPP) sebesar 1,25 persen dan menjadi LPP terendah sepanjang sejarah pelaksanaan sensus penduduk yang dilakukan sejak tahun 1961. Pada tahun 1961 LPP Indonesia mencapai 2,10 persen dan terus mengalami peningkatan hingga mencapai 2,31 persen pada tahun 1980. Sementara dari segi persebarannya, lebih dari 


\section{Elastisitas - Jurnal Ekonomi Pembangunan \\ Vol. 3 No. 2, September 2021}

setengah penduduk Indonesia masih terpusat di Pulau Jawa, diikuti dengan pulau Sumatera, Sulawesi, Kalimantan, dan Bali-Nusa Tenggara. Sedangkan Maluku dan Papua dengan kumulatif jumlah penduduk hanya sebesar 8,6 juta masih merupakan yang terendah seIndonesia (Yuyun Yuningsih, 2021).

Sementara dari segi kualitas, penduduk Indonesia masih tergolong rendah yang diindikasikan oleh tingkat pendidikan yang relative rendah, angka kemiskinan tinggi, tingkat kematian yang masih cukup tinggi dan secara umum Indeks Pembangunan Manusia (IPM) yang masih rendah. Indeks Pembangunan Manusia (IPM) Indonesia berada pada urutan ke 6 dari 11 negara ASEAN yaitu 0,707, dibawah Singapura, Brunai Darussalam, Malaysia, Thailand dan Filipina (Jalaludin, 2020).

Gambar 1.

Indeks Pembangunan Manusia (IPM) Indonesia dibandingkan dengan negara-negara ASEAN 2019

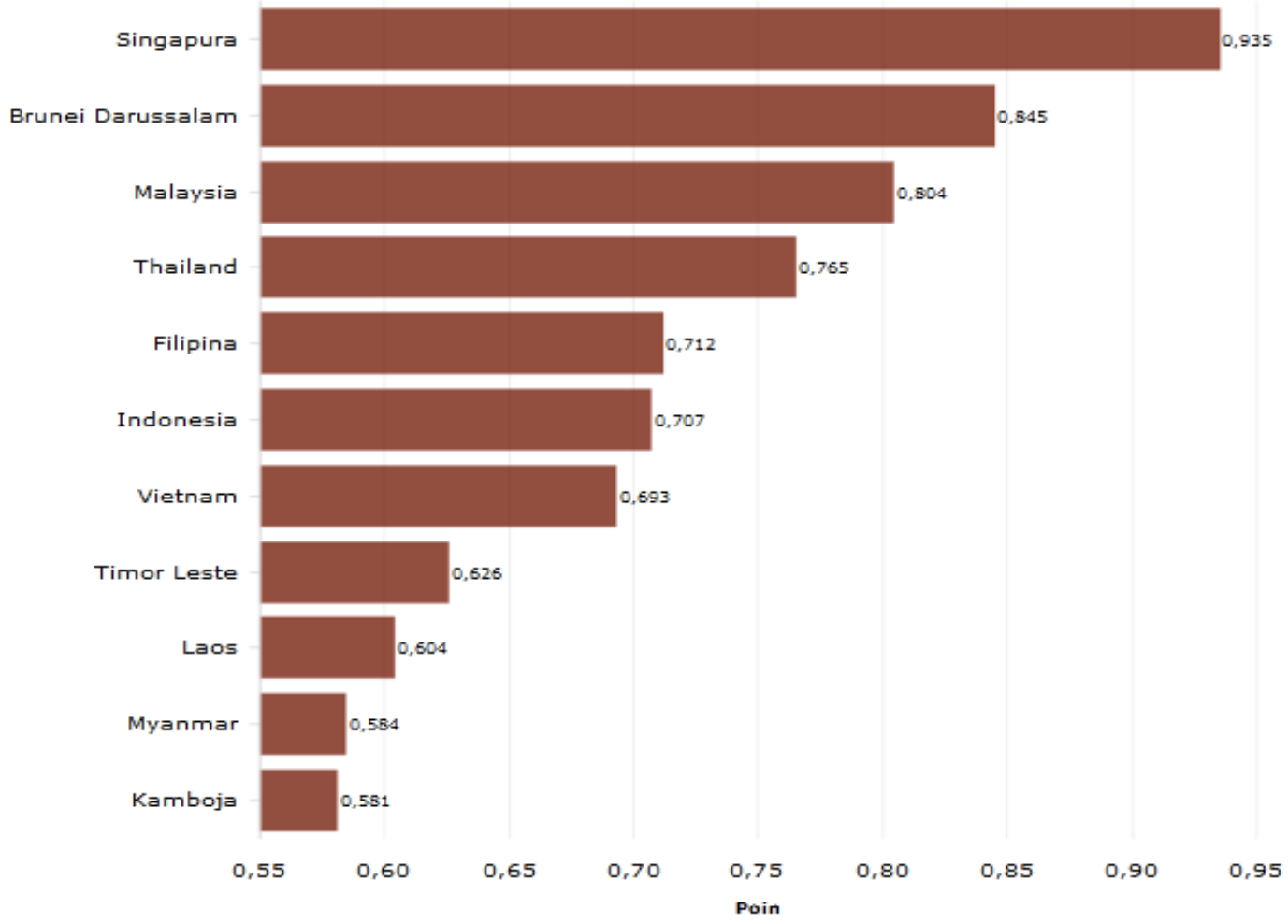

Sumber : United Nation Developmen Program (UNDP), 2019

Disisi lain, akibat keberhasilan pengendalian kuantitas dan peningkatan kualitas penduduk yang terjadi beberapa dekade terakhir, menyebabkan terjadinya perubahan ciri dan struktur penduduk. Menelaah masalah kependudukan dua matra utama mesti diperhatikan yaitu aspek kuantitas dan kualitas, dimana keduanya bisa dikaji melalui tren, sebaran, pertumbuhan dan komposisinya, Sementara proses demografi seperti Fertilitas, Mortalitas dan migrasi adalah faktor faktor yang mempengaruhi dinamika kependudukan itu sendiri. Proses kependudukan seperti mobilitas dan persebaran bisa menjadi faktor 
penting yang bisa menghambat laju pembangunan sustu negara atau daerah. Terkait dengan penomena kependudukan tersebut, tulisan ini mencoba menelaah persoalan yang terkait dengan mobilitas dan persebaran pendudk yang terjadi di provinsi Nusa Tenggara Barat (NTB) dalam kurun waktu sepuluh tahun terahir.

\section{MOBILITAS PENDUDUK PROVINSI NTB}

Persebaran dan mobilitas penduduk ibarat dua sisi mata uang yang tidak dapat dipisahkan dan keduanya merupakan determinan penting dalam kerangka pengendalian penduduk. Membicarakan masalah migrasi atau mobilitas penduduk, tidak begitu berarti bila tidak dikaitkan dengan masalah persebaran penduduk, demikian pula sebaliknya menyelesaikan persoalan persebaran penduduk tidak mungkin dilakukan tampa mobilisasi atau perpindahan penduduk. Mobilitas atau perpindahan penduduk memiliki pengertian yang sangat luas dimana setiap perpindahan spasial fisik ataupun grafis dinyatakan sebagai suatu aktivitas migrasi atau mobilitas penduduk.

Mobilitas atau migrasi penduduk secara definisi diartikan sebagai perpindahan penduduk dengan tujuan untuk menetap dari suatu tempat ke tempat lain melampaui batas politik/ negara maupun batas administrasi/ batas wilayah dalam suatu negara. Perpindahan penduduk tersebut tentu dapat dilakukan dengan keinginan sendiri ataupun diprogramkan oleh pemerintah. Mobilitas penduduk juga diartikan sebagai gerak atau perpindahan penduduk dari suatu wilayah (geografis ) ke wilayah lain dalam jangka waktu tertentu. Mobilitas penduduk juga diartikan sebagai gerak keruangan penduduk dengan melewati batas administrasi daerah tingkat II (Ari Welianto, 2020). Mobilitas penduduk dapat dilihat dalam arti fisik, yaitu perpindahan penduduk untuk memperoleh peluang dan kesempatan yang lebih luas di tempat lain (mobilitas horizontal). Dalam arti sosial, ekonomi, dan budaya, yaitu upaya peningkatan status melalui peningkatan kesejahteraan (mobilitas vertikal).

Mobilitas penduduk muncul sebagai akibat dari perkembangan fenomena sosial ekonomi nasional maupun regional. Perbedaan karakteristik ruang dan sumber daya yang dimiliki di berbagai wilayah mendorong penduduk melakukan mobilitas penduduk. Perbedaan tersebut mencukup juga pergerakan sumber daya berupa barang antar ruang. Jadi mereka melakukan mobilitas untuk memperoleh sesuatu yang tidak tersedia di daerah asalnya. Orang yang melakukan mobilitas penduduk disebut migran. Pada dasarnya mobilitas penduduk merupakan respons manusia terhadap situasi dan kondisi yang sedang terjadi. Seperti desakan ekonomi, situasi politik, kebutuhan pendidikan, gangguan keamanan, atau terjadinya bencana alam di daerah asal. Di satu sisi mobilitas penduduk akan berdampak terhadap persebaran penduduk, dan persebaran penduduk yang tidak seimbang akan berpengaruh terhadap proses pembangunan regional bahkan nasional, sehingga migrasi yang terencana mutlak dilakukan.

Mobilitas atau perpindahan penduduk sangat terkait dengan aktivitas pembangunan suatu daerah, proses pembangunan tidak akan terjadi tanpa adanya mobilitas penduduk, dan pengarahan penyebaran penduduk akan sulit dilakukan tanpa adanya kegiatan pembangunan. Kenyataan menunjukkan bahwa meningkatnya aktivitas migrasi beberapa decade terahir terjadi karena peningkatan sarana dan prasarana transportasi, komonikasi, industrialisasi dan pertumbuhan ekonomi.

Perbedaan tingkat pembangunan yang terjadi baik antar kawasan maupun 


\section{Elastisitas - Jurnal Ekonomi Pembangunan \\ Vol. 3 No. 2, September 2021}

daerah menjadi alasan utama bagi seseorang untuk melakukan perpindahan/ bermigrasi. Orang akan mempertimbangkan dan memutuskan untuk bermigrasi/ berpindah ke tempat atau daerah yang lebih potensial dan pembangunannya lebih menjanjikan dari daerah asalnya, dengan harapan kesejahteraannya akan lebih baik atau meningkat. Dalam hal ini Provinsi Nusa
Tenggara Barat (NTB) telah lama menjadi daerah tuajuan migrasi yang ditunjukkan oleh migrasi netto yang positif dalam tiga decade terahir. Berdasarkan data Survey Antar Sensus (SUPAS) berbagai tahun terlihat trend atau perkembangan mobilitas atau migrasi penduduk baik yang masuk maupun yang keluar NTB seperti terlihat dalam gambar 1 berikut ini.

Gambar 2.

Migrasi Risen Masuk dan Keluar NTB 1980- 2020

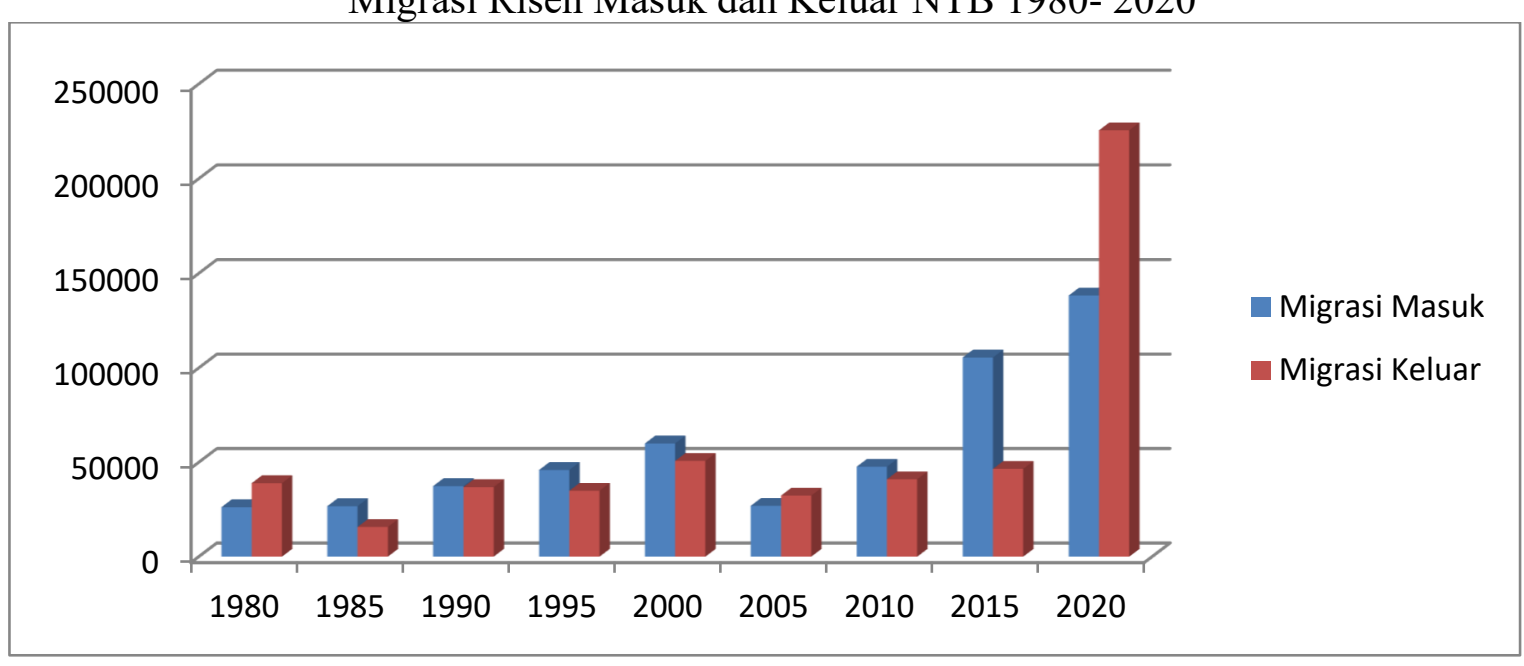

Sumber : BPS, BPS NTB : Susenas berbagai tahun

Berdasarkan gambar 2 di atas, selama kurun waktu satu dekade terahir provinsi NTB mengalami net migrasi atau migrasi netto yang posotiv dalam arti jumlah migrasi masuk selalu lebih besar dari migrasi keluar, kecuali tahun 1980 dan 2005.dan 2020 Migrasi netto posistif terbesar terjadi pada tahun 2015, dimana jumlah migran yang masuk adalah sebesar 105 ribu lebih sementara migran yang keluar NTB kurang dari setengah migran yang masuk ke NTB yaitu sebesar 46 ribu orang. Hal ini dimungkinkan karena geliat ekonomi dan pembangunan di NTB selama beberapa decade terahir menunjukkan peningkatan yang cukup significant. Namun demikian terjadi migrasi netto negatif yang sangat inggi pada tahun 2020, dimana migrasi masuk ke NTB sebanyak 138.284 orang sementara yang keluar sebanyak 225.514 orang. Hal ini boleh jadi disebabkan karena pada saat survey dilakukan tahun 2019, sudah merebak covid 19 sehinggamobilitas manusia sudah dibatasi dengan adanya penyekatan masuk dan keluar NTB sehingga orang sudah keluar NTB terutama para warga migran yang bekerja yang sempat pulag kampun menjadi tidak bisa kembali masuk akibat penyekatan pintu masuk NTB pada saat survey SUSENAS dilaksanakan.

Dengan adanya mobilitas atau perpindahan penduduk, pembangunan di daerah tujuan migrasi semakin berkembang karena para migran umumnya adalah angkatan kerja dan biasanya memiliki semangat kerja dan 


\section{Elastisitas - Jurnal Ekonomi Pembangunan \\ Vol. 3 No. 2, September 2021}

semangat untuk maju yang besar dibandingkan dengan masyarakt local/ tempatan. Disamping itu kehadiran para migrant, dapat menciptakan lapangan kerja baru yang dapat mendukung pertumbuhan ekonomi daerah tujuan. Hal ini terkonfirmasi oleh meningkatnya perekonomian NTB yang dicerminkan oleh peningkatan Product Domestic Regional Bruto (PDRB), baik atas dasar harga berlaku maupun atas dasar harga konstan 2000 seperti terlihat pada gambar 2 berikut ini.

Gambar 3.

Pertumbuhan Ekonomi NTB 2010- 2020 (persen)

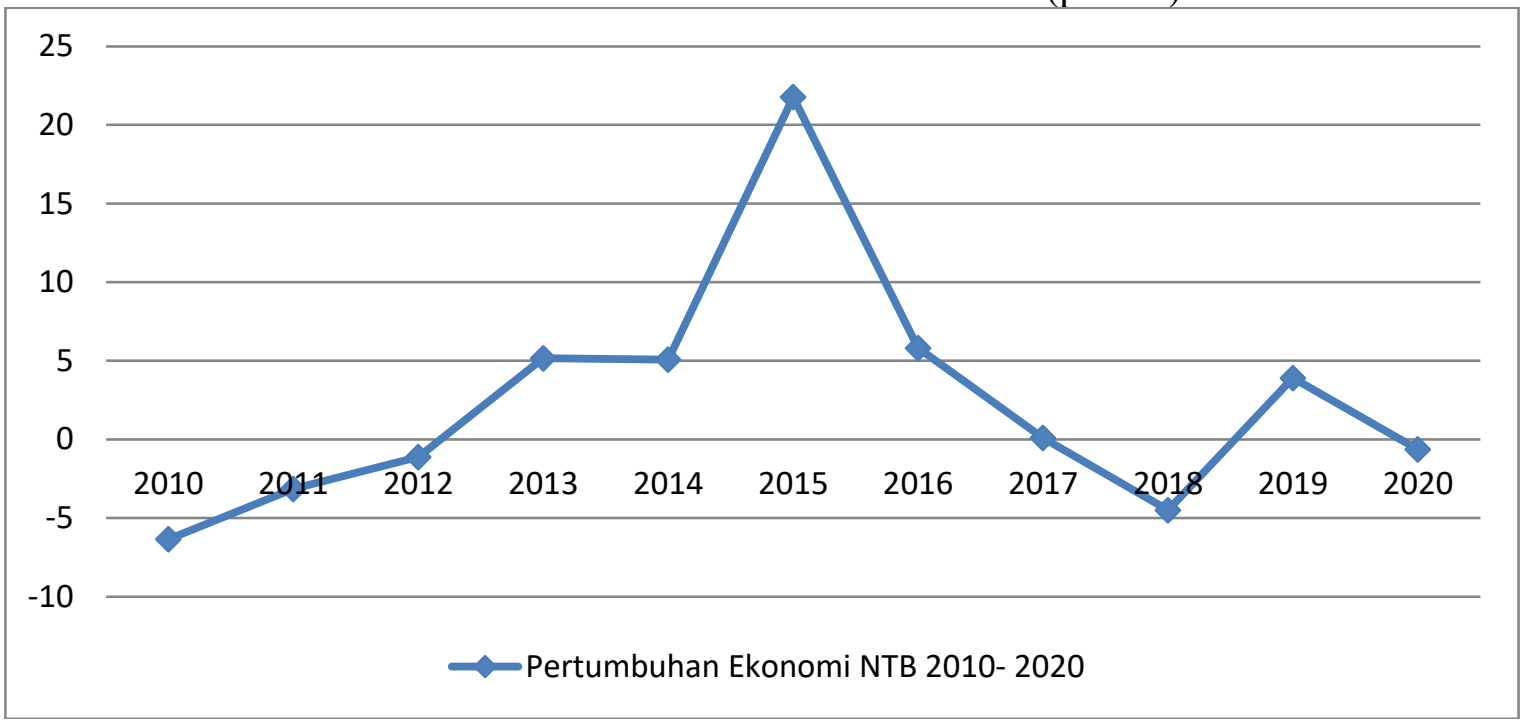

Sumber : BPS NTB, NTB dalam Angka Berbagai Tahun diolah

Berdasarkan gambar 3 di atas, terlihat bahwa pertumbuhan ekonomi NTB selama kurun waktu satu dekade terahir mengalami pluktuasi dari $-6,35$ persen pada tahun 2010 meningkat menjadi 5,16 persen pada tahun 2013 dan relatif melambat bahkan stagnan pada tahun 2014 dan mengalami peningkatan yang sangat tinggi pada tahun 2015 yaitu sebesar 22,77 persen. Hal ini sekaligus mengkorfirmasi peningkatan migrasi masuk yang sangat tinggi pada tahun 2015 seperti yang terungkap pada gambar 3. Pada tahun 2016 pertumbuhan ekonomi NTB terjun bebas menjadi 5,81 persen dan sempat mines yaitu $-4,5$ persen pada tahun 2018 sebelum ahirnya positive 3,9 persen pada tahun 2019 dan turun lagi menjadi -0,64 pada tahun 2020 . Peluktuasi pertumbuhan ekonomi NTB terutama yang terjadi pada dua tahun terahir ini sedikit banyak dipengaruhi oleh situasi ekonomi nasional yang juga mengalami kontraksi akibat wabah covid 19 yang melanda Indonesia sejak dua tahun terahir.

Paralel dengan pertumbhan ekonomi, kondisi ekonomi NTB secara absolut berdasarkan nilai PDRB, berdasarkan harga berlaku maupun atas dasar harga konstan juga mengalami peningkatan selama kurun waktu satu dekade terahir.. 


\section{Elastisitas - Jurnal Ekonomi Pembangunan \\ Vol. 3 No. 2, September 2021}

Gambar 4.

PDRB NTB ADH Berlaku dan ADH Konstan 2010- 2020

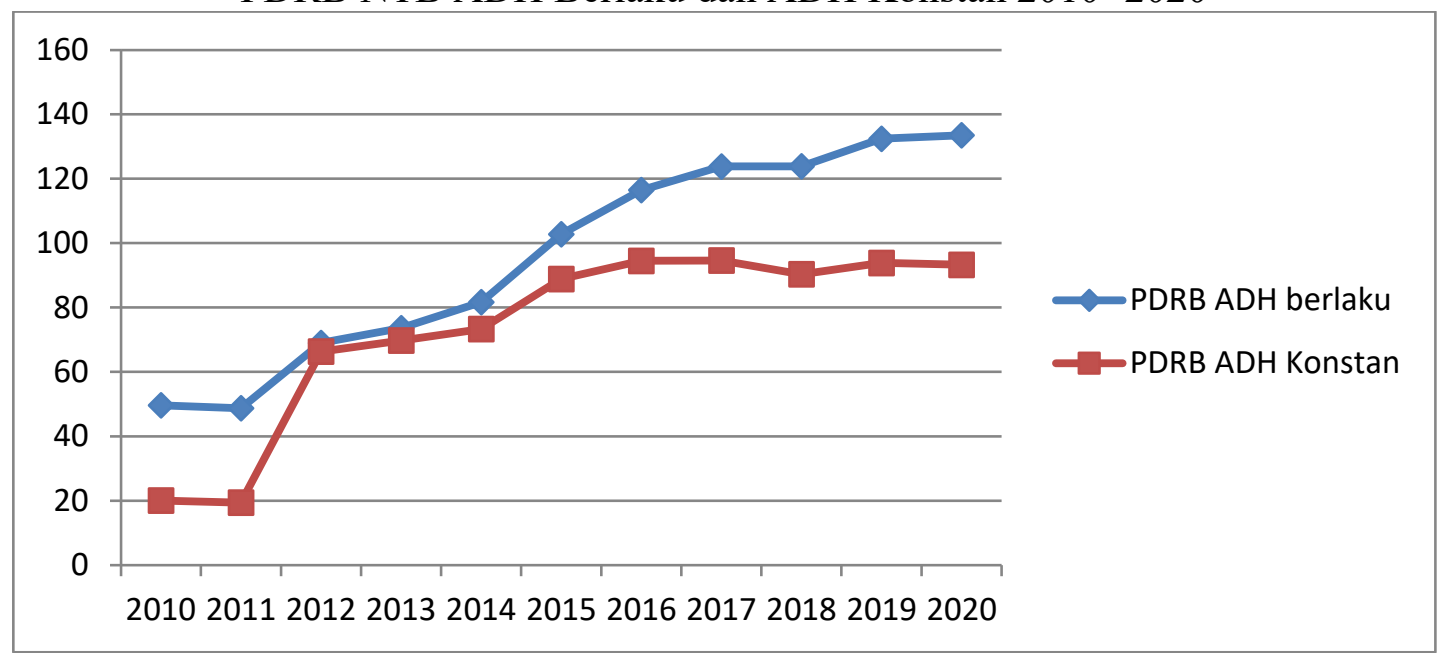

Sumber : BPS NTB : PDRB NTB, NTB dalam Angka berbagai tahun diolah.

Dari gambar 4 di atas dapat diketahui bahwa secara umum PDRB NTB mengalami peningkatan dalam kurun waktu satu dekade terahir baik atas dasar harga berlaku maupun berdasarkan harga konstan, walaun terjadi perlambatan bahkan penurunan pada tahun 2018 dan 2019. Berdasarkan harga berlaku PDRB NTB meningkat dari 49,63 triliun pada tahun 2010 menjadi 133,52 triliun rupiah tahun 2020. Demikian pula PDRB ADH Konstan yang meningkat dari 20,07 triliun tahun
2010 menjadi 93,27 triliun pada tahun 2020

Paralel dengan peningkatan PDRB, kesejahteraan masyarakt yang diukur berdasarkan pendapatan perkapita atau PDRB perkapita juga mengalami peningkatan. Hal ini menunjukkan bahwa sejalan dengan arus migrasi risen yang positif selama beberapa decade terahir, saat yang sama juga terjadi peningkatan aktivitas ekonomi yang pada gilirannya meningkatkan kesejahteraan masyakat.

Gambar 5.

PDRB Perkapita, NTB, 2010- 2020

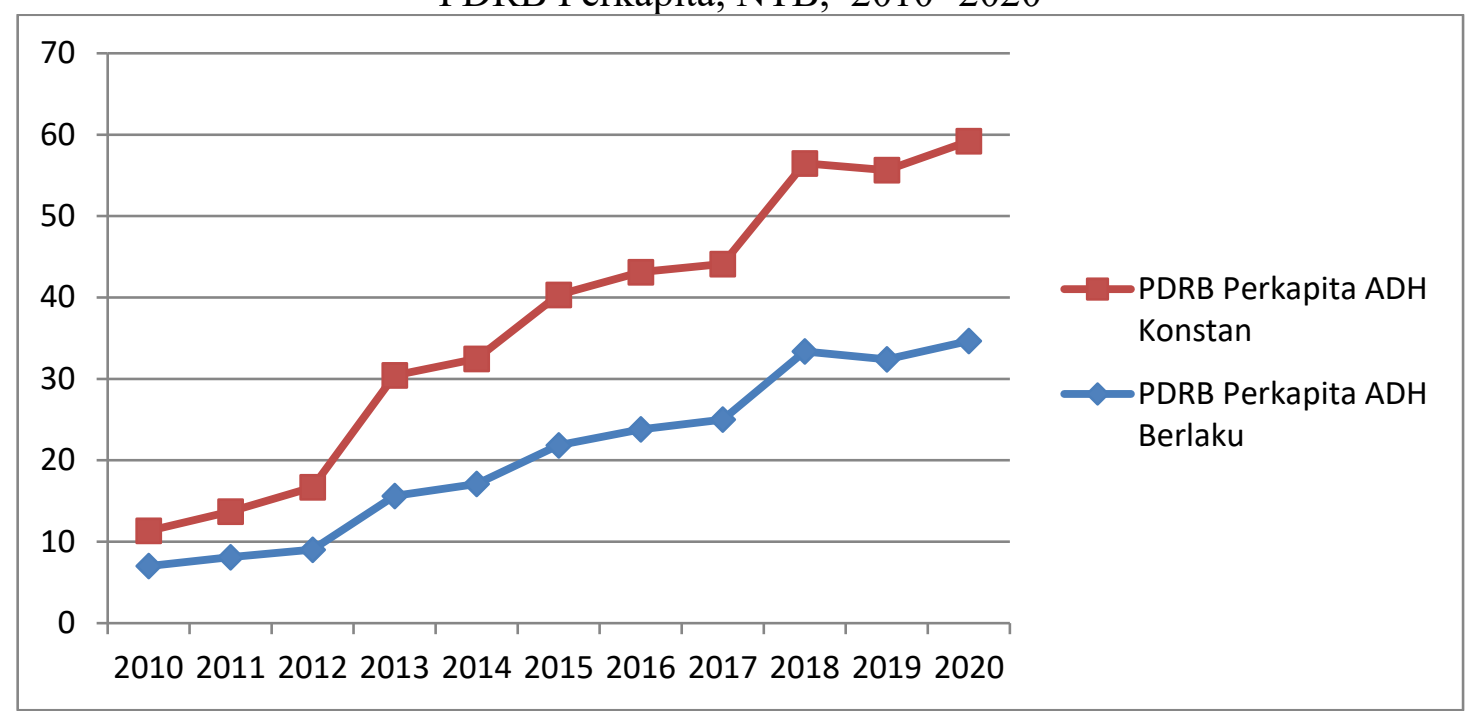

Sumber : BPS NTB, NTB Dalam Angka, berbagai tahun diolah 
3. JUMLAH, LPP DAN

PERSEBARAN PENDUDUK NTB

Selain berdampak terhadap peningkatan ekonomi dan kesejahteraan, adanya mobilitas atau perpindahan penduduk juga menyebabkan terjadinya perubahan terhadap persebaran penduduk NTB. Persoalan distribusi atau persebaran penduduk di NTB tidak jauh berbeda dengan yang terjadi secara nasional dimana selain jumlah penduduknya yang relative besar juga persebarannya yang tidak merata.

Jumlah penduduk NTB tahun 2020 sebanyak 5.32 juta jiwa, terdiri dari 2.656 juta laki- laki dan 2.664 juta perempuan. Kontribusi penduduk NTB secara nasional adalah 1,9 persen terhadap penduduk Indonesia secara keseluruhan. Dengan jumlah penduduk sebanyak itu menempatkan NTB terutama pulau Lombok menjadi salah satu pulau yang memiliki penduduk terpadat di Indonesia setelah pulau jawa dan Bali.
Laju pertumbuhan penduduk (LPP) NTB dalam kurun waktu beberapa dekade terahir menunjukkan tren yang menurun. Pada periode tahun 1971- 1980, pertumbuhan penduduk NTB masih tinggi yaitu mencapai 2,36 persen. Sepuluh tahun kemudian yaitu periode 1980- 1980 pemerintah daerah mampu menurunkan LPP NTB menjadi 2,15 persen dan menjadi 1,29 persen pada periode 1990- 2000. Berdasarkan SP 2010 laju pertumbuhan penduduk NTB mencapai angka 1,17 lebih rendah dibanding LPP Indonesia sebesar 1,47 sekaligus menempatkan NTB sebagai provinsi dengan LPP terrendah ke lima secara nasional. Namun berdasarkan SP 2020, LPP NTB kembali meningkat menjadi 1,63 persen yang menyebakan NTB naik kembali ke posisi provinsi atau daerah dengan LPP menengah. Dengan demikian komitmen daerah untuk mempertahankan LPP rendah kembali mendapat tantangan dan sekaligus menjadi pekerjaan rumah pemerintah daerah dalam bidang kependudukan di NTB.

Gambar 6.

Jumlah dan Laju pertumbuhan Penduduk NTB 1971 - 2020

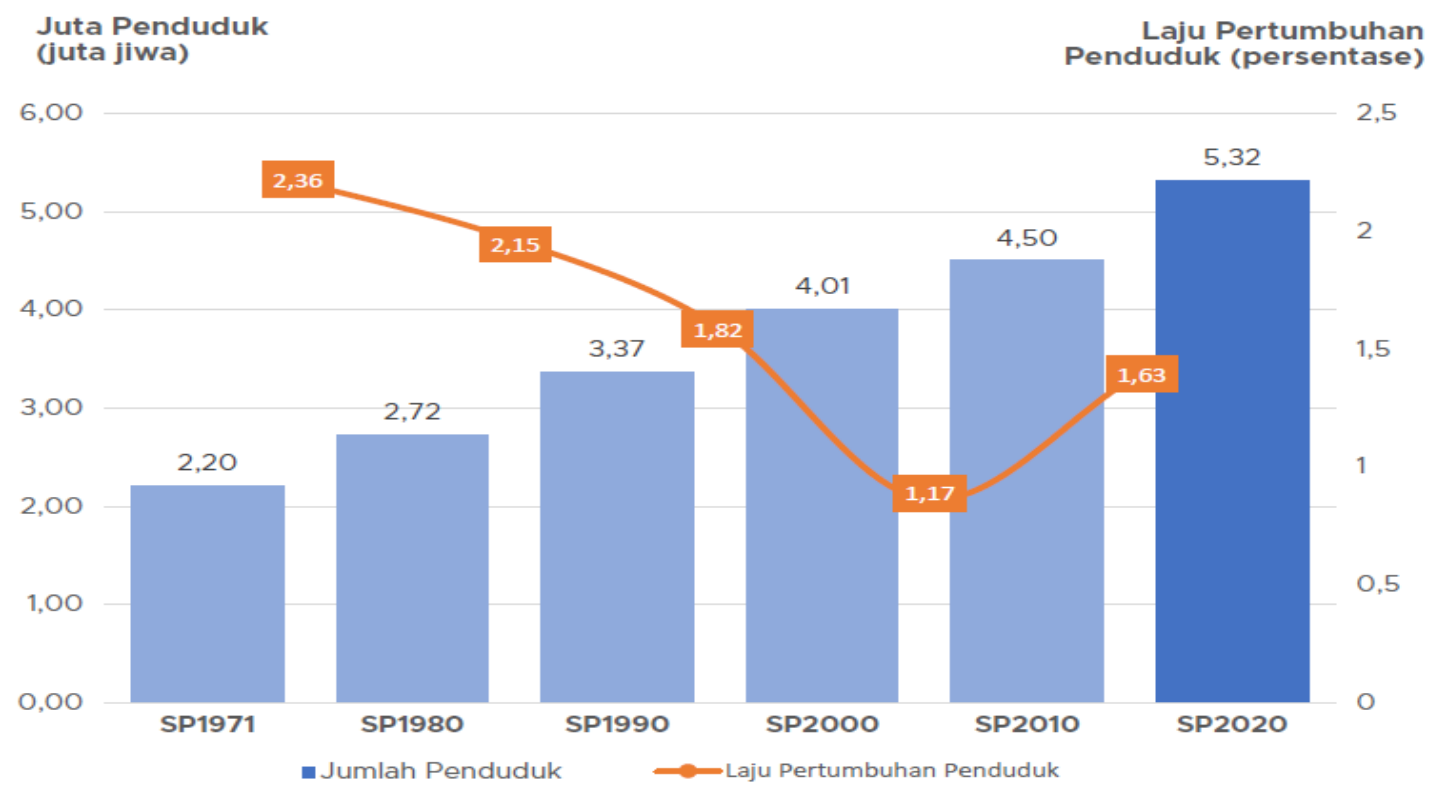


Dari sisi persebaran penduduk, NTB tergolong timpang karena dari 5.320.092 jiwa penduduk NTB pada tahun 2020, 70,41 persen tinggal di pulau Lombok sementara sisanya 28,59 persen mendiami pulau Sumbawa, padahal pulau Lombok luasnya hanya sepertiga dari luas pulau Sumbawa. Artinya persebaran penduduk NTB berbanding terbalik dengan luas wilayah atau pulau yang dimiliki. Bila persebaran penduduk dilihat berdasarkan kabupaten/ kota kondisinya tidak jauh berbeda dimana dari 10 kabupaten/ kota yang ada di NTB kabupaten Lombok Timur merupakan kabupaten dengan jumlah penduduk terbesar, yaitu 1.325.240 jiwa (24,91 persen). Sementara kabupaten Lombok Tengah dengan jumlah penduduk sebanyak 1.034.859 jiwa (19,45 persen) menempati urutan kedua penduduk terbesar di NTB.

Gambar 7.

Persebaran Penduduk NTB 2020

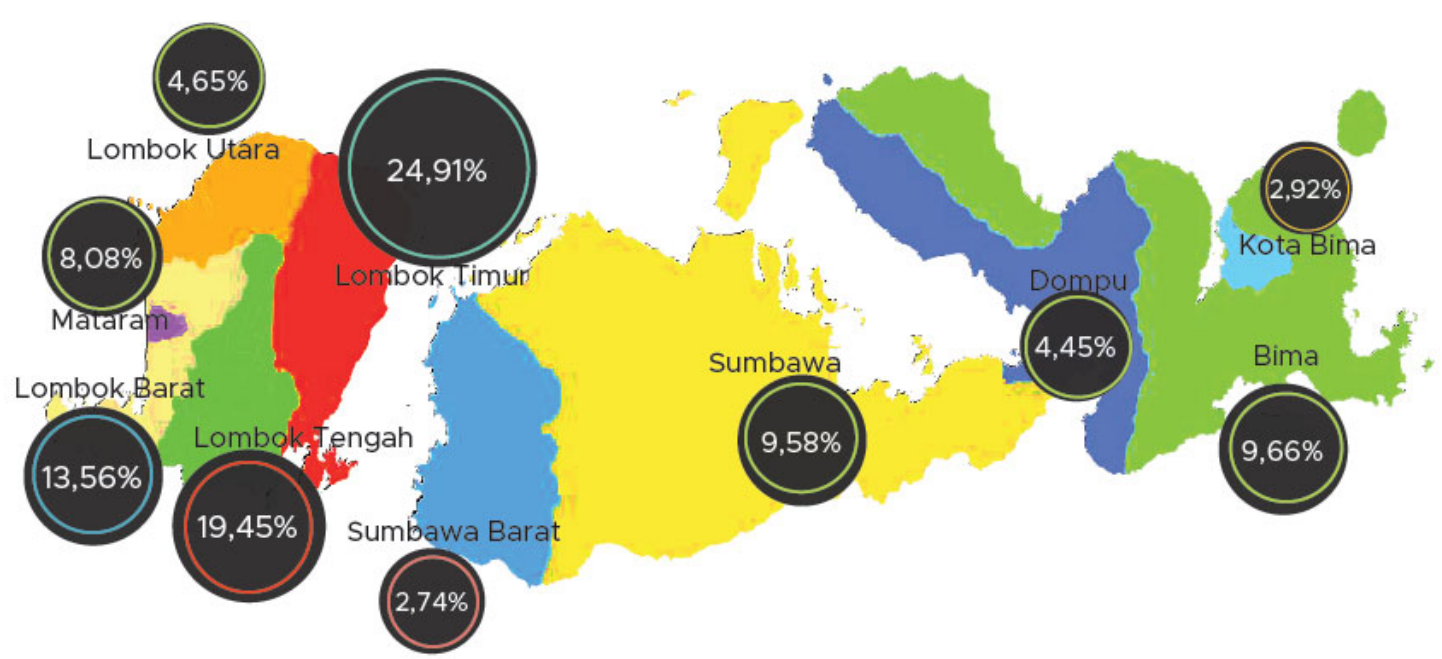

Distribusi atau persebaran penduduk antara kabupaten/ kota di NTB, tergolong timpang dimana hampir setengahnya terkonsentrasi di dua kabupaten di pulau Lombok yaitu kabupaten Lombok Timur dan kabupaten Lombok Tengah. Jumlah penduduk kedua kabupaten ini adalah 2.360.009 atau 44,36 persen dari penduduk NTB yang berjumlah 5.320.092 jiwa. Sementara dua kabupaten yang memiliki penduduk paling sedikit adalah kabupaten Sumbawa Barat (KSB) yang memiliki jumlah penduduk sebanyak 145.798 jiwa dan Kota Bima 155.140 jiwa atau krang dari 3 persen penduduk NTB yang kedua kabupaten/ kota berada di pulau Sumbawa.

\section{PENUTUP/REKOMENDASI}

Aktivitas mobilisasi atau perpindahan penduduk telah memungkinkan aktivitas ekonomi dan pembangunan di daerah NTB menjadi semakin berkembang. Dampak lanjutan dari adanya peningkatan aktivitas ekonomi dan pembangunan ini adalah terjadinya peningkatan PDRB, yang pada gilirannya dapat meningkatkan kesejahteraan masyarakt. Disisi lain mobilitas penduduk juga membawa dampak ikutan yaitu persebaran penduduk tidak merata sehingga aktivitas ekonomi menjadi timpang yang pada gilirannya kesejahteraan penduduk juga menjadi tidak merata.

Untuk memmaksimalkan tujuan peningkatan kesejahteraan penduduk 
melalui aktivitas migrasi atau mobilitas penduduk ini, maka hal- hal berikut perlu dilakukan : 1).Kebijakan mobilitas penduduk harus diarahkan untuk pemerataan persebaran penduduk yang disesuaikan dengan kondisi dan potensi yang dimiliki oleh tiap daerah. 2). Mengidentifikasi karakteristik dan potensi ekonomi yang dimiliki masingmasing daerah. Hal ini dapat dilakukan dengan melakukan kajian dan pemetaan ekonomi di masing- masing kabupaten/ kota yang ada di NTB. 3). Untuk mengatasi persoalan persebaran penduduk yang belum merata, pemerintah perlu meningkatkan eskalasi pembangunan ekonomi di pulau Sumbawa. Hal ini dapat dilakukan dengan meningkatkan investasi melalui penyederhanaan perizinan, dan bila perlu memberikan insentif kepada para investor yang akan berinvestasi di pulau Sumbawa. 4). Disamping itu perlu digalakkan kembali transmigrasi local (translok) dan transmigrasi swakarsa. Hal ini dapat dilakukan dengan memberikan kemudahan dalam pengurusan izin kepindahan atau administrasi kependudukan lainnya, dan bila perlu meberikan insentif kepada para transmigran yang memiliki keahlian tertentu sesuai dengan kebutuhan daerah tujuan.

\section{REFRENSI}

Badan Pusat Statistik NTB, Data Sensus Penduduk 2020 dan berbagai tahun

Badan Pusat Statistik NTB, PDRB NTB, 2020 dan Berbagai Tahun

Badan Pusat Statistik NTB, NTB Dalam Angka, 2021dan Berbagai Tahun

Jalaludin, 2020, Dinamika Kependudukan NTB : Analisis Variabel Sosio Demografik, Jurnal Ekonobis, Maret 2020
Muhajir Darwin, 2010, Dinamika Kependudukan \& Penguatan Governance, Yogyakarta, Media Wacana

Setiadi, Dr, M.Si, 2012, Indikator Mobilitas, Yogyakarta, Pusat Studi Kependudukan dan Kebijakan Universitas Gajah Mada.

Welianto Ari : Mobilitas Penduduk, Definisi dan Jenis https://www.kompas.com/skola/rea $\mathrm{d} / 2020 / 07 / 10 / 194500169$, diakses tanggal 2 Juli 2021

Yuyun Yuningsih ; Hasil SP 2020 :https://kumparan.com/yuyunyuningsih1613524268198874728/hasilsp2020-laju-pertumbuhanpenduduk-indonesia-masih-tinggi$1 \mathrm{vBx} 19 \mathrm{CtCS} 9 /$ full diunduh tanggal 14 Juli 2021

Zubaidah Hanum : Hari Populasi Dunia dan Masalah Kependudukan di Indonesia : https://mediaindonesia.com/humanio ra/327330/ diunduh tanggal 14 Juli 2021 